\title{
Genetic heterogeneity in the major histocompatibility complex of various BB rat sublines
}

\author{
I. Kryspin-Sørensen, T. Dyrberg and W. Kastern \\ Hagedorn Research Laboratory, Gentofte, Denmark
}

\begin{abstract}
Summary. Fragments of cloned rat class I transplantation antigen genes were used to define the polymorphism detected between two lines of closely related BB rats. One line, BBHagedorn $(\mathrm{BB} / \mathrm{H})$, is prone to diabetes, and the other $(\mathrm{BB}$ control) is resistant. A cDNA probe representing part of the second extracellular domain of a class I antigen detected several DNA fragments and revealed a $2 \mathrm{~kb}$ fragment present in resistant, but absent in diabetes-prone, $\mathrm{BB} / \mathrm{H}$ rat $\mathrm{DNA}$ following digestion with BamH1. A $40 \mathrm{bp}$ cDNA probe from the same domain showed a further simplified pattern in the DNA hybridization analysis. Only two fragments, $15 \mathrm{~kb}$ and $7 \mathrm{~kb}$, were present in the resistant rats; the diabetes-prone $\mathrm{BB} / \mathrm{H}$ rats lacked the $7 \mathrm{~kb}$ fragment. Several lines of evidence suggest
\end{abstract}

that the gene contained in this $7 \mathrm{~kb}$ fragment may be deleted. Analysis of other diabetic $\mathrm{BB}$ rats and in the $\mathrm{F}_{2}$ generation of intercross offspring of $F_{1}$ hybrid parents following crossbreeding between the resistant (BB-control) and diabetesprone $(\mathrm{BB} / \mathrm{H})$ line demonstrate that the class I polymorphism was not linked directly to diabetes. Examination of various other BB lines and sublines indicate that these polymorphisms can be traced back to at least one other subline (Worcester) in the parent colony.

Key words: Major histocompatibility complex, BB rat, restriction fragment polymorphisms.
The diabetic BB rat has proven to be a valuable model for the study of Type 1 (insulin-dependent) diabetes. The parallels between diabetes in both the rat and man are numerous [1-3], and the freedom of experimentation inherent in an animal model has led to an understanding of the disease which was previously impossible.

Like its human counterpart, the onset of diabetes in the rat has an important immunological component with many lines of evidence indicating that it is an autoimmune disease. Briefly, the results of experiments demonstrating passive transfer of diabetes to non-diabetes prone rats [4], prevention of diabetes by neonatal thymectomy [5], rabbit anti-rat lymphocyte serum [6] and the presence of lymphocytic thyroiditis [7], as well as anti-islet $[8,9]$ and other autoantibodies $[10,11]$, all indicate that an autoimmune mechanism is involved in $\mathrm{BB}$ rat diabetes.

The genetics of diabetes in the BB rat remains unclear. However, breeding studies, in which crosses were made between $B B$ rats and other strains of rats with either the same or different tissue types, demonstrated that there may be as many as two or three separate genetic components, with one linked to the major histo- compatibility complex (MHC) and the other independent of it $[12,13]$. Thus, a gene (or genes) within the MHC may provide part of the clue for the mechanism of diabetes as well as other autoimmune diseases. Indeed, many research efforts are currently directed at the characterization of this component.

Since the discovery of diabetes-prone rats in the BioBreeding facility in Canada in 1974 [14], several laboratories have developed inbred lines of these rats [15]. These inbred lines, showing high, low or no incidence of diabetes, are all assumed to be closely related, since they were all derived from the original BB colony. However, since the original BioBreeding colony was not maintained as inbred [1], some genetic heterogeneity can be considered to have been present at the beginning of, and maintained throughout, the inbreeding process.

Many types of studies with the BB rat, both genetic and immunological, require a knowledge of the degree of relationship between various inbred diabetic and control strains. It is particularly important to have the ability to test this relationship, especially within the MHC, because differences within the MHC can have a pronounced effect on experimental data even though the differences may not be linked to diabetes. An aware- 
ness of MHC differences is also necessary in order to compare results, not only within a laboratory, but also between laboratories. The classical techniques of serology and tissue transplantation are of only limited use in this context because, due to various defects within their immune system, diabetic BB rats are unable to reject foreign tissue [16]. Moreover, the MHC is composed of nearly 40 genes, as seen by molecular cloning studies [17], with only a few of these genes detectable by classical immunological techniques. Thus, these techniques cannot accurately assess the relationship between various BB lines.

One tool that is becoming increasingly useful in genetic analysis in general, and in analysis of the MHC in particular, is the detection of restriction fragment length polymorphism (RFLP) by Southern blotting. With a suitable DNA probe, one is able to screen a gene, or family of genes, for DNA base changes or small insertions or deletions of DNA sequence which remove, insert, or rearrange restriction enzyme sites. Thus, genetic differences between animals can be quickly and easily detected regardless of the availability of the gene product or an assay for it.

We have previously used these techniques to detect an RFLP within the MHC of an inbred non-diabetic BB-control line which was absent from our inbred diabetic $\mathrm{BB} / \mathrm{H}$ line [18]. The presence of this 2 kilobase (kb) BamH1 fragment within the class I MHC of BBcontrol rats, as well as an additional $7 \mathrm{~kb}$ BamH1 fragment, provides excellent markers for the inheritance of the diabetic MHC chromosome as well as the uniformity of the MHC between various BB lines. We report here further characterization of these polymorphic fragments and their use in genetic analysis of the MHC in the $\mathrm{BB}$ rat.

\section{Materials and methods}

The diabetic line, $\mathrm{BB} /$ Hagedorn $(\mathrm{BB} / \mathrm{H})$, and the w-subline control animals, $\mathrm{BB}$ control, used in these studies were as described previously [18]. The $\mathrm{BB} / \mathrm{H}$ rats had been kept in brother-sister breeding at the Hagedorn Research Laboratory since the tenth generation of inbreeding. The rats included in the present study were obtained in the 15-18th generations. The BB control animals were from Dr. A. Like (University of Massachusetts, Worcester, Mass., USA), and were in their 10th generation of inbreeding. Both $\mathrm{BB} / \mathrm{H}$ and $\mathrm{BB}$ control rats were maintained in a parallel inbreeding program. In the 19 th generation of inbreeding of the two lines, a diabetic $\mathrm{BB} / \mathrm{H}$ female was mated with a $B B$ control male to yield 10 non-diabetic $F_{1}$ rats. Three $F_{1}$ breeding pairs were obtained to give a total of 34 litter mates in two subsequent matings. Type 1 diabetes developed in $25 \%$ of the $\mathrm{F}_{2}$ animals. The diabetic BB $\times$ LEH line resulted from a cross between $\mathrm{BB}$ rats and Long Evans Hooded rats and were a gift from Dr. J. Logothetopoulos (University of Toronto, Canada), and were maintained as a separate colony in our laboratory. The BB-Düs line originated in the Ottawa colony, and was a gift from Dr. L. Herberg (University of Düsseldorf, FRG). The various strains of the $\mathrm{BB} / \mathrm{W}$ were obtained from Dr. D. Guberski (University of Massachusetts). The strains, as well as their average age of onset of diabetes and percent incidence, are as follows: BA $(100$ days $/ 60 \%)$, BB (90d $/ 74 \%), \mathrm{BE}(105 \mathrm{~d} /<50 \%)$, BF $(100 \mathrm{~d} / 60 \%), \mathrm{BP}(105 \mathrm{~d} /<50 \%)$ and NB $(90 \mathrm{~d} / 65 \%)$.
Total genomic DNA was either prepared from the livers of freshly killed rats as described [18] or from a section of the tail from living animals. Approximately $2 \mathrm{~cm}$ of the tail was removed, frozen in liquid $\mathrm{N}_{2}$, pulverized with a mortar and pestle, and then digested with proteinase $\mathrm{K}$ followed by phenol/chloroform extraction as described for liver nuclei preparations [18].

Restriction enzyme digestions, agarose gel electrophoresis, Southern blotting, nick translation, and DNA hybridization and washing were performed according to our previous description [18]. When hybridizations were performed under less stringent conditions, they were incubated overnight at $37^{\circ} \mathrm{C}$, then washed in the same buffers as described [18], except that the temperature was lowered to $42^{\circ} \mathrm{C}$.

The probes used in this study were mouse $\mathrm{pH} 2 \mathrm{~d}-1$ as described [18]; pKA19, a cDNA clone consisting of the region coding for the second extracellular domain of a rat class I antigen; pIWO-2, an HpaII/Alu I restriction fragment of pKA19 subcloned into the AccI site of plasmid pUC-8 [19]. The class II probes were derived as follows: $\mathrm{E} \alpha$ probe, a $700 \mathrm{bp}$ Pstl fragment from the mouse $\mathrm{E} \alpha$ gene; $\mathrm{E} \beta$ probe, a $500 \mathrm{bp}$ PstI fragment of the mouse $\mathrm{E} \beta$ gene; $\mathrm{A} \alpha$ probe, a $1300 \mathrm{bp}$ CfoI fragment of the mouse $\mathrm{A} \alpha$ gene; and $\mathrm{A} \beta$ probe, an $800 \mathrm{bp} C$ foI fragment of the mouse $\mathrm{A} \beta$ gene. All probes were derived from the coding sequences of their respective genomic clones, a gift from Dr. R. Germain (NIH, Bethesda, MD, USA).

\section{Results}

\section{Class I gene polymorphism}

The class I MHC region of the Hagedorn strain of BB rat was previously reported to contain a restriction fragment length polymorphism seen as the absence of a $2 \mathrm{~kb}$ band that was present in the BB control line [18]. The DNA probe used in that study in a different set of rats (Fig. 1A) was a cDNA clone containing most of the coding region of a mouse class I MHC gene. However, the complexity of this family of genes in the rat precluded a more thorough assessment of the size of this band or the presence of other polymorphisms in the diabetic line. Progressively smaller fragments were therefore used as probes of Southern blots to eliminate as many of the non-polymorphic bands as possible, and resulted in a more simplified banding pattern. When a cDNA clone (pKA19) containing approximately onehalf of the region coding for the second extracellular domain of a rat class I protein was used as a radioactive probe of $\mathrm{BamH} 1$ digests of total DNA from $\mathrm{BB} / \mathrm{H}$ and BB control rats, the pattern was indeed much simpler (Fig. 1B). The $2 \mathrm{~kb}$ band was well separated from the others and was clearly present in the $\mathrm{BB}$ controls and absent from the diabetic $\mathrm{BB} / \mathrm{H}$ rats (Fig. 1A). When screened with this probe, the DNA from all of the control animals $(12 / 12)$ and none of the diabetic animals $(0 / 12)$ had the $2 \mathrm{~kb}$ band.

While the pKA19 probe resulted in a simpler banding pattern, we were still unable to resolve the high molecular weight region of the gel. Since this mass of genes could obscure any further polymorphisms between the two rat lines, a number of smaller probes were constructed by digesting the insert of pKA19 with frequent cutting restriction enzymes and ligating them to the bacterial plasmid, pUC8. Of the clones thus obtained, one 


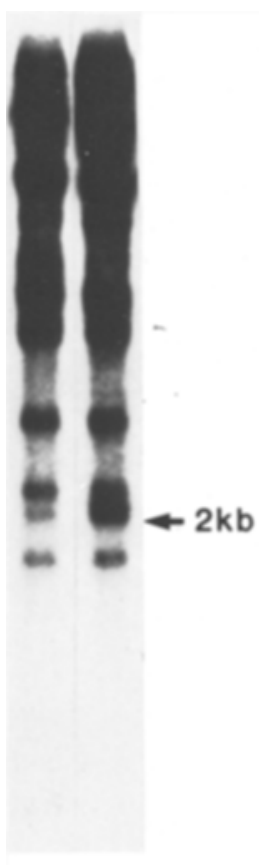

A

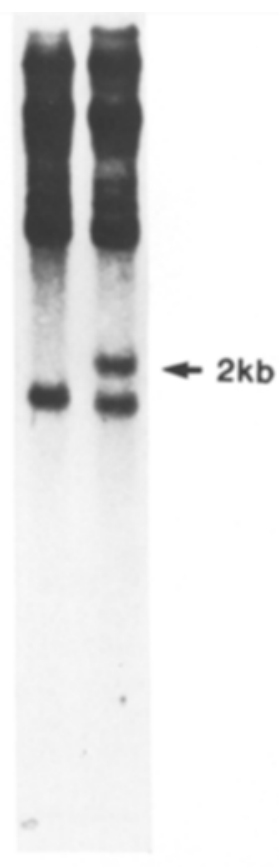

B

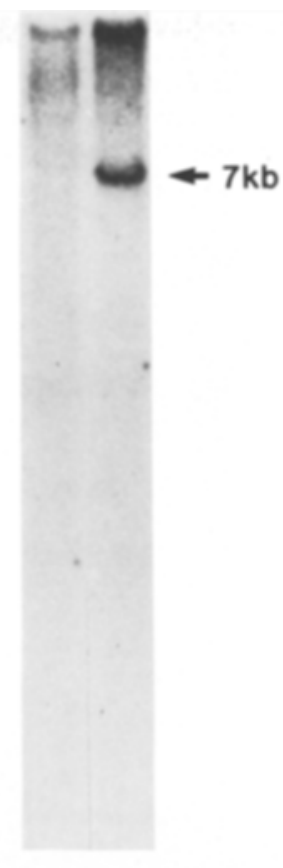

C

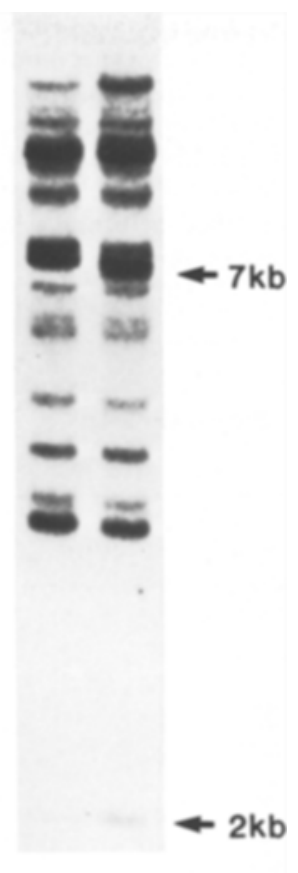

D
Fig. 1 A-D. Class I MHC restriction fragment length polymorphisms using fragments of cloned class I cDNA. DNA from either $\mathrm{BB} / \mathrm{H}$ or $\mathrm{BB}$ control rats was digested with BamHI and blotted to nitrocellulose after electrophoresis for $15 \mathrm{~h}$ in $1 \%$ agarose gels. The pair of lanes to the left in each panel were from $B B / H$ rats; those to the right were from $\mathrm{BB}$ control. The ${ }^{32} \mathrm{P}$-labeled DNA probes were $A$ mouse $\mathrm{pH} 2^{\mathrm{d}}, \mathbf{B}$ rat pKA19, C rat pIWO-2, D rat pKA19 and subjected to electrophoresis for twice as long

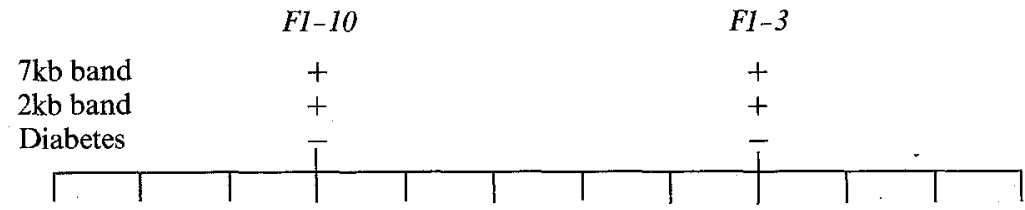

$\begin{array}{lllllllllllllll}F 2-20 & F 2-21 & F 2-22 & F 2-23 & F 2-24 & F 2-25 & F 2-26 & F 2-27 & F 2-28 & F 2-29 & F 2-30 & F 2-31\end{array}$

$\begin{array}{ccccccccccccc}7 \mathrm{~kb} \text { band } & + & + & + & + & + & \mathrm{NA} & + & \mathrm{NA} & + & - & + & - \\ 2 \mathrm{~kb} \text { band } & + & + & + & + & + & \mathrm{NA} & + & \mathrm{NA} & + & - & + & - \\ \text { Diabetes } & - & + & + & - & - & - & - & + & - & - & - & -\end{array}$

Fig. 2. The $F_{1}$ and $F_{2}$ generations from one of the families resulting from a cross between a female $\mathrm{BB} / \mathrm{H}$ and a male $\mathrm{BB}$ control rat. Each animal was tested for the presence of the $2 \mathrm{~kb}$ and $7 \mathrm{~kb}$ polymorphic class I MHC bands by hybridizing either ${ }^{32} \mathrm{P}-\mathrm{pKA19}(2 \mathrm{~kb})$ or ${ }^{32} \mathrm{P}-\mathrm{pIWO}-2$ (7 kb) to Southern blots of BamHI digests of DNA from each animal. They were followed for the development of diabetes up to 180 days
(pIWO-2) detected a striking polymorphism against a simple background when used to probe BamH1 digests of DNA from the two rat lines. Only two bands $(15 \mathrm{~kb}$ and $7 \mathrm{~kb}$ ) were detected in the BB control animals; one of the bands, at approximately $7 \mathrm{~kb}$, was absent from the diabetic $\mathrm{BB} / \mathrm{H}$ rats (Fig. $1 \mathrm{C}$ ).

While the hybridization of this probe to the control rat DNA was quite strong, the possibility existed that the pIWO-2 fragment did not form a stable hybrid with the diabetic rat DNA due to its small size (approximately 40 base pairs). We eliminated this possibility by running the agarose gel at a higher voltage and for a longer time so as to resolve the high molecular weight region of the gel. A blot of this gel was then probed with the original cloned cDNA fragment (pKA19) from which pIWO-2 was derived. The larger size of this fragment ( $200 \mathrm{bp}$ ) would insure a stable hybrid with all the bands to which the smaller piece hybridized. The resulting autoradiograph (Fig. 1D) clearly demonstrated hybridization to the $7 \mathrm{~kb}$ band in the $\mathrm{BB}$ control animals and $\mathrm{ab}$ - sence of hybridization to any corresponding band in the $\mathrm{BB} / \mathrm{H}$ rats.

The observation of two polymorphic class $\mathrm{MHC}$ genes in diabetic $\mathrm{BB} / \mathrm{H}$ rats as compared to the $\mathrm{BB}$ control rats led to the question of whether the inheritance of either the $2 \mathrm{~kb}$ or the $7 \mathrm{~kb}$ bands was linked to the absence of diabetes in the BB controls. To test this link, rats from the control strain were bred with diabetic rats. The two lines of rats were in their 19th generation of separate sister-brother breeding. In the $F_{1}$ generation, as expected, the animals did not develop diabetes; in addition, all of the progeny were positive for both the $2 \mathrm{~kb}$ and the $7 \mathrm{~kb}$ bands. It is important to note that heterozygotes can only be scored as positive in these Southern blots, since it is impossible to differentiate between one positive and two positive chromosomes on the blot.

To further follow the inheritance of these traits, crosses were made between littermates of the $F_{1}$ generation. A typical family from this cross (Fig. 2) had two diabetic rats in the $F_{2}$ generation, with both developing 
Table 1. Summary of the inheritance of the $2 \mathrm{~kb}$ and $7 \mathrm{~kb}$ class I restriction fragment polymorphisms and diabetes in the $F_{2}$ generation of a cross between a female diabetic $\mathrm{BB} / \mathrm{H}$ and a male $\mathrm{BB}$ control rat. DNA was extracted from the tail and cut with BamHI prior to Southern blotting. The ${ }^{32} \mathrm{P}$-labeled DNA probes were pKA19 ( $2 \mathrm{~kb}$ band) and pIWO-2) ( $7 \mathrm{~kb}$ band). The animals were followed for diabetes until 180 days of age. Two additional diabetic rats died before DNA could be prepared, and were not included in these numbers

\begin{tabular}{llllll}
\hline \multicolumn{1}{c}{ Bands } & & & & \\
\hline & $7 \mathrm{~kb}(-)$ & $7 \mathrm{~kb}(+)$ & $7 \mathrm{~kb}(-)$ & $7 \mathrm{~kb}(+)$ & 0 \\
& $2 \mathrm{~kb}(-)$ & $2 \mathrm{~kb}(+)$ & $2 \mathrm{~kb}(+)$ & $2 \mathrm{~kb}(-)$ & Total \\
& $\mathrm{n}=10$ & $\mathrm{n}=55$ & $\mathrm{n}=7$ & $\mathrm{n}=6$ & $\mathrm{n}=78$ \\
\hline $\begin{array}{l}\text { Diabetic } \\
\text { rats }(\%)\end{array}$ & $1(10)$ & $10(18)$ & $2(29)$ & $2(33)$ & $15(19)$ \\
\hline
\end{tabular}

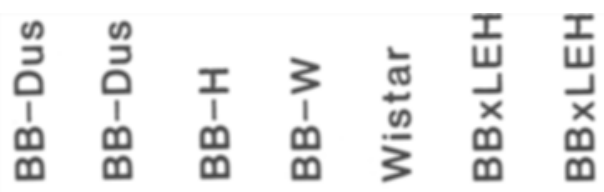

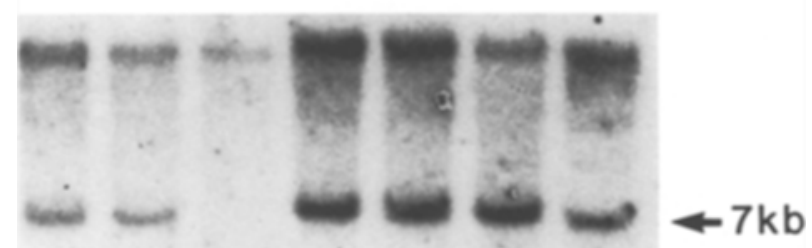

Fig. 3. Presence of the $7 \mathrm{~kb}$ polymorphic class I MHC band in related BB lines. BamHI digests of DNA were probed with ${ }^{32} \mathrm{P}-\mathrm{pIWO}-2$. BBDüs represents 2 rats from the $\mathrm{BB} / \mathrm{Düs}$ line. $\mathrm{BB} / \mathrm{H}$ is a diabetic rat and $\mathrm{BB}-\mathrm{W}$ is a $\mathrm{BB}$ control rat from our colony. Wistar is a commercially available Wistar rat. $\mathrm{BB} \times \mathrm{LEH}$ resulted from a cross between a BB line and Long Evans Hooded rats

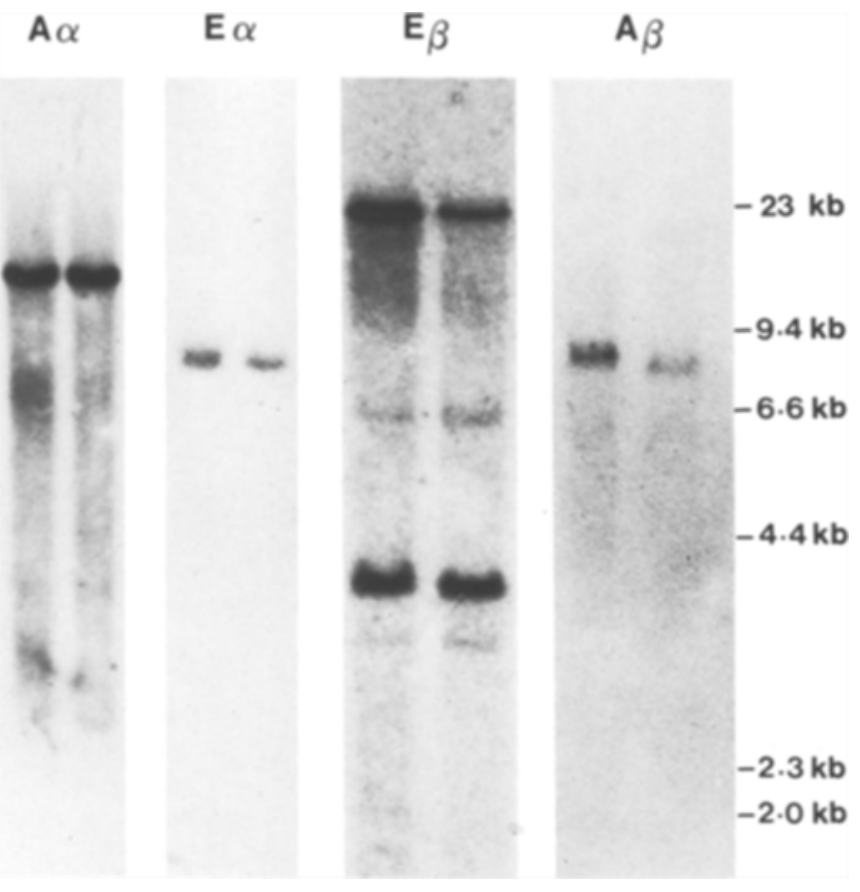

Fig.4. Screening BB rat DNA for class II MHC restriction fragment length polymorphisms. DNA was digested with EcoRI. The left lane in each panel is $\mathrm{BB} / \mathrm{H}$ DNA; the right lane is $\mathrm{BB}$ control. The probes used were ${ }^{32} \mathrm{P}$-labeled fragments of the coding regions of mouse $\mathrm{A} \alpha$, $\mathrm{E} \alpha, \mathrm{AB}$ or $\mathrm{E} \beta$ genes

the disease at approximately 80 days of age. However, both of these rats inherited both the $2 \mathrm{~kb}$ and the $7 \mathrm{~kb}$ bands (Fig. 2). Conversely, none of the rats lacking the two bands subsequently developed diabetes, despite the fact that they were followed for 180 days.

The data from all four families are summarized in Table 1 . Out of 15 diabetic rats observed in this generation, only one missed both the $2 \mathrm{~kb}$ and $7 \mathrm{~kb}$ bands. Two of the diabetic rats lacked the $2 \mathrm{~kb}$ band while retaining the $7 \mathrm{~kb}$ band, and therefore were considered possible recombinants along with four of the non-diabetic rats. Additionally, two diabetic rats and five control rats lacked the $7 \mathrm{~kb}$ but had the $2 \mathrm{~kb}$ band (Table 1). The data indicate therefore that the polymorphic class I MHC appeared to be inherited independently of the diabetic trait.

The absence of these two bands in the BB/Hagedorn rats raised the question about whether other diabetic $\mathrm{BB}$ rat strains also contain these polymorphisms. We tested the $\mathrm{BB} \times \mathrm{LEH}$, which is a line resulting from a cross of a male diabetic BB rat of the original Ottawa colony with a Lewis Hooded rat and the diabetic BB/ Düs rats for the presence of the $7 \mathrm{~kb}$ band. All rats tested, four diabetic BB $\times$ LEH and five BB/Düs, had the $7 \mathrm{~kb}$ band upon hybridization with the pIWO-2 probe (Fig.3). The presence of the $2 \mathrm{~kb}$ band was not tested for in these rats.

Since both the BB/H and BB/control lines were derived from the colony at Worcester, we tested several sublines of inbred rats from that colony. Of the sublines 
tested (BA, BB, BE, BF, BP and NB), at least two of them, the $B A$ and $B B$ sublines, clearly lacked both the $2 \mathrm{~kb}$ and $7 \mathrm{~kb}$ polymorphic fragments. Thus, the polymorphisms detected in the $\mathrm{BB} / \mathrm{H}$ line could be traced back to at least two sublines in the parent Worcester colony, and were not a recent genetic accident.

\section{Class II gene polymorphisms}

A more detailed rescreening of the class II MHC region for RFLP was carried out, since earlier studies with human $\mathrm{DR} \alpha$ and human $\mathrm{DQ} \beta$ chain cDNA clones as probes did not reveal polymorphism between $\mathrm{BB} / \mathrm{H}$ and $\mathrm{BB}$ control rats [18]. The possibility that these probes lacked adequate homology with the analogous rat genes was tested using mouse genomic clones as probes. DNA preparations from $\mathrm{BB} /$ Hagedorn and $\mathrm{BB}$ control rats were digested with either BamH1, EcoR1 or Pst1, blotted to nitrocellulose and probed with fragments from the coding regions of either mouse $\mathrm{A} \alpha, \mathrm{A} \beta$, $\mathrm{E} \alpha$, or $\mathrm{E} \beta$ genes. After hybridization and subsequent washing under conditions of very low stringency so as to allow the detection of bands with a minimum of homology, no polymorphic bands between the diabetic $\mathrm{BB} / \mathrm{H}$ and $\mathrm{BB}$ control rats were seen with any of the probes (Fig.4).

\section{Discussion}

Previous observations of a restriction fragment length polymorphism in the diabetic $\mathrm{BB} / \mathrm{H}$ line when compared with our inbred control BB line [18] were extended here to include both a $2 \mathrm{~kb}$ and a $7 \mathrm{~kb}$ BamH1 band. These bands were absent in all of the $\mathrm{BB} / \mathrm{H}$ animals tested, and they were detected using probes derived from fragments of a region of cDNA coding for the second extracellular domain of a rat class I MHC antigen. While all of the BB/Hagedorn animals missed both of these bands, breeding studies failed to reveal any linkage between the inheritance of the bands and the incidence of diabetes. However, the absence of these bands in at least one subline in the Worcester colony indicated that the genetic event that resulted in the loss of the two polymorphic fragments happened at least 14 generations previously and had been stably maintained ever since.

The presence of these two polymorphic fragments provides valuable markers in genetic studies of the $\mathrm{BB}$ rat. On the one hand, they are useful for demonstrating the lack of uniformity in the MHC between various lines of the BB rat. Knowledge of this is important in many studies where genetic variations in the MHC could affect various immune phenomena such as the rejection of transplants. Laboratories involved in these studies should be aware that their inbred lines may differ in the MHC even though the rats may still be RTI haplotype. However, the presence of these two poly- morphic fragments in all strains examined except the $\mathrm{BB} / \mathrm{H}$ and the $\mathrm{BB} / \mathrm{W}-\mathrm{BB}$ subline allow one to follow the MHC chromosomes from these two lines specifically through generations of crosses with other lines. Thus, a more accurate assessment of the role played by the MHC chromosome in the development of diabetes can be obtained.

We have not yet localized precisely the actual defect which caused the loss of the $7 \mathrm{~kb}$ band in the $\mathrm{BB} /$ Hagedorn line. This fragment contains a class I MHC gene as seen by its hybridization with a cloned rat class I MHC cDNA probe and by analysis of a genomic clone of this fragment from the BB control line (Kryspin-Sørensen and Kastern, unpublished observations). The inability of the pIWO-2 (Fig. 1B-D) probe, or any of the others we have tested, to hybridize to an analogous band in the $\mathrm{BB} /$ Hagedorn line suggested that at least a portion of this gene was deleted in the line. A close inspection of Figure $1 \mathrm{C}$ and Figure 3 indicated that the intensity of the $15 \mathrm{~kb}$ band in the $\mathrm{BB} / \mathrm{H}$ line is insufficient to account for the shift of the $7 \mathrm{~kb}$ band to this higher molecular weight (i.e. after the loss of a single BamHl site) in these animals.

A deletion within a class I gene could have profound effects on an organism and could explain any of a number of immune dysfunctions in these animals. The polymorphisms described here seemed not to be related to lymphopenia, since only a few of the F2 animals were even mildly lymphopenic, and these could not be correlated with the inheritance of the bands (Dyrberg and Kastern, unpublished observations). Due to the high homology between various class I genes and their protein products, it is possible that the production of one class I protein could compensate for the loss of another so as to prevent lethality. However, in a system where the substitution of a single amino acid could cause profound autoimmune reactions [20], this possibility is unlikely. The absence of the $2 \mathrm{~kb}$ and $7 \mathrm{~kb}$ bands correlated very strongly with the absence of a serum $\beta_{2}$-microglobulin immunoreactive component [21]. Since $\beta_{2}$-microglobulin associates with class I MHC antigens, this suggests that the absence of this component indicates the loss of a class I antigen species. However, the function of this serum fraction is unknown, and any number of the immune defects observed in the BB line could be attributed to the loss of a circulating class I antigen.

Other than the two restriction fragment length polymorphisms described here, we have not observed any other polymorphisms between the $\mathrm{BB} / \mathrm{H}$ and $\mathrm{BB}$ control lines. This includes detailed studies involving different restriction enzyme digestions, different probes and different hybridization conditions. Moreover, the studies have included both the class I and class II MHC regions using either rat or closely related mouse DNA probes. Using outbred BB rats from the Ottawa colony, both class I and class II polymorphisms have been detected by others [22, 23]. The significance of these obser- 
vations is unclear, since the control $\mathrm{BB}$ line $(\mathrm{BBN})$ is known to have $\mathrm{RTI}^{\mathrm{a}}$ specificities in addition to the $\mathrm{RTI}^{\mathrm{u}}$ of the diabetic lines [24]. Moreover, the $7 \mathrm{~kb}$ BamH1 band reported here would not have been detected in those studies, since only a small fragment of a rat-specific probe (such as pIWO-2), could detect the band. Thus, we conclude that, at least at the level of resolution of these techniques, there are no major differences in the $\mathrm{MHC}$ of the $\mathrm{BB} / \mathrm{H}$ diabetic and the non-diabetic $\mathrm{BB}$ control animals. This is not surprising, since the two lines are very closely related and maintained through strict inbreeding. At this point, we cannot exclude other genetic variations not detected by these methods. For example, point mutations not affecting a restriction enzyme site or variations in the levels of expression of any of these genes could also account for the lymphopenia, autoimmunity, appearance of Type 1 diabetes or other facets of the BB rat syndrome.

Our observation of 13 apparent recombination events in the $F_{2}$ generation of the crosses between the $\mathrm{BB} /$ Hagedorn and the $\mathrm{BB}$ control lines suggest either that the $2 \mathrm{~kb}$ and $7 \mathrm{~kb}$ genes are quite distant from each other on the chromosome, or that the MHC in the BB line is a kind of recombination hotspot. These putative recombinant chromosomes were stably inherited in Mendelian fashion as seen by crosses of some of these animals with animals lacking both the $2 \mathrm{~kb}$ and $7 \mathrm{~kb}$ bands (data not shown). We have observed from molecular cloning experiments that the $2 \mathrm{~kb}$ and $7 \mathrm{~kb}$ fragments are not neighbours, and may well lie quite distant from each other on the chromosome. However, this alone cannot explain two recombinant events in a single family of 13 pups. Indeed, we have observed several instances where the progeny produced new banding patterns unlike those seen in the parents, particularly in the class II region (data not shown). Therefore, it may be possible that the MHC of the BB rat does contain recombinational instability, and that this instability may contribute to the susceptibility towards diabetes.

Acknowledgements. We would like to thank Dr. A. Lernmark for comments and criticism and H. Laursen for excellent technical assistance. We also thank Drs. R. Germain for the mouse class II genes, L. Herberg for the BB/Düs rats, and D.Guberski for the various Worcester lines.

\section{References}

1. Marliss EB, Nakhooda AF, Poussier P, Sima AA (1982) The diabetic syndrome of the "BB" Wistar rat: possible relevance to type I (insulin-dependent) diabetes in man. Diabetologia 22: 225-232

2. Like AA, Rossini AA (1984) Spontaneous autoimmune diabetes mellitus in the Biobreeding Worcester rat. Surv Synth Pathol Res 3: 131-138

3. Rossini AA, Mordes JP, Like AA (1985) Immunology of insulindependent diabetes mellitus. Ann Rev Immunol 3: 289-320

4. Koevary S, Rossini AA, Stoller W, Chick WL, Williams RM (1983) Passive transfer of diabetes in the BB/w rat. Science 220: 727-728

5. Like AA, Kislauskis E, Williams RM, Rossini AA (1982a) Neonatal thymectomy prevents spontaneous diabetes mellitus in the $\mathrm{BB} / \mathrm{w}$ rat. Science 216 : 644-646
6. Like AA, Rossini AA, Guberski DL, Williams RM (1979) Spontaneous diabetes mellitus: reversal and prevention in the $\mathrm{BB} / \mathrm{w}$ rat with antiserum to rat lymphocytes. Science 206: 1421-1423

7. Sternthal E, Like AA, Sarantis K, Braverman LE (1981) Spontaneous and iodide-induced lymphocytic thyroiditis in the diabetic BioBreeding/Worcester ( $\mathrm{BB} / \mathrm{w})$ rat. A model of autoimmune endocrinopathy. Diabetes 30:1058-1061

8. Dyrberg T, Nakhooda AF, Baekkeskov S, Lernmark Å, Poussier $P$, Marliss EB (1982) Islet cell surface antibodies and lymphocyte antibodies in the spontaneously diabetic BB Wistar rat. Diabetes 31: 278-281

9. Baekkeskov S, Dyrberg T, Lernmark $\AA$ (1984) Autoantibodies to a 64 kilodalton islet cell protein precede the onset of spontaneous diabetes in the BB rat. Science 224: 1348-1350

10. Elder M, Maclaren N, Riley W, McConnell T (1982) Gastric parietal and other autoantibodies in the BB rat. Diabetes 31:313-318

11. Like AA, Appel MC, Rossini AA (1982b) Autoantibodies in the $\mathrm{BB} / \mathrm{w}$ rat. Diabetes $31: 816-820$

12. Colle E, Guttmann RD, Seemayer T, Michel F (1983) Spontaneous diabetes mellitus syndrome in the rat. IV. Immunogenetic interactions of $\mathrm{MHC}$ and non-MHC components of the syndrome. Metabolism 32: 54-61

13. Guttmann RD, Colle E, Michel F, Seemayer TA (1983) Spontaneous diabetes mellitus syndrome in the rat. II. T-lymphopenia and its association with clinical disease and pancreatic lymphocytic infiltration. J Immunol 130: 1732-1735

14. Chappel CJ, Chappel WR (1983) The discovery and development of the BB rat colony: An animal model of spontaneous diabetes mellitus. Metabolism 32 (Suppl 1): 8-10

15. Butler L, Guberski DL, Like AA (1983) The effect of inbreeding on the BB/w diabetic rat. Metabolism 32 (Suppl 1): 51-53

16. Elder M, Maclaren N (1983) Identification of profound peripheral T lymphocyte immunodeficiencies in the spontaneously diabetic BB rat. J Immunol 130: 1723-1731

17. Steinmetz M, Winato A, Minard K, Hood L (1982) Clusters of genes encoding mouse transplantation antigens. Cell 28: 489-498

18. Kastern W, Dyrberg T, Schøller J, Kryspin-Sørensen I (1984) Restriction fragment polymorphisms in the major histocompatibility complex of diabetic BB rats. Diabetes 33: 807-809

19. Vieria J, Messing J (1982) The pUC plasmids, an M13mp7-derived system for insertion mutagenesis and sequencing with synthetic universal primers. Gene 19:259-268

20. Maron R, Klein J, Cohen IR (1982) Mutations at H-2K or H-2D alter immune response phenotype of autoimmune thyroiditis. Immunogenetics 15: 625-627

21. Björck L, Kryspin-Sørensen I, Dyrberg T, Lernmark A, Kastern W (1986) A deletion in a rat major histocompatibility complex class I gene is linked to the absence of $\beta_{2}$-microglobulin-containing serum molecules. Proc Natl Acad Sci USA (in press)

22. Buse JB, Chaplin DD, Ben-Nun A, Klein KA, Eisenbarth GS, Seidman JG, Jackson RA (1984) Class I, II and III major histocompatibility gene polymorphisms in BB rats. Diabetologia 27: $77-79$

23. Buse JB, RiPai-Haddad R, Lees S, Taniguchi H, Chaplin D, Milford EM, Seidman JG, Eisenbarth GS, Jackson RA (1985) Major histocompatibility restriction fragment length polymorphisms define three diabetogenic haplotypes in BB and BBN rats. J Exp Med 162: 444-458

24. Klöting I, Hubner R, Stark O (1983) Major histocompatibility complex (MHC)-independent differences between diabetes-prone BB rats and their parental Wistar rat strain in some hematologic and metabolic traits. Res Exp Med 182: 231-236

Received: 23 October 1985

and in revised form: 5 March 1986

Dr. William Kastern

Hagedorn Research Laboratory

Niels Steensensvej 6

DK-2820 Gentofte

Denmark 